\title{
Benign Spinal Cord Neoplasm
}

National Cancer Institute

\section{Source}

National Cancer Institute. Benign Spinal Cord Neoplasm. NCI Thesaurus. Code C3627.

A primary, non-invasive neoplasm without metastatic potential affecting the spinal cord.

Representative examples include dermoid cyst, lipoma, and neurofibroma. 